Article

\title{
How Does the Development of the Social Enterprise Sector Affect Entrepreneurial Behavior? An Empirical Analysis
}

\author{
Ana Fernández-Laviada, Carlos López-Gutiérrez ${ }^{D}$ and Andrea Pérez * ${ }^{D}$ \\ University of Cantabria, 39005 Santander, Spain; ana.fernandez@unican.es (A.F.-L.); \\ carlos.lopez@unican.es (C.L.-G.) \\ * Correspondence: perezran@unican.es
}

Received: 30 December 2019; Accepted: 20 January 2020; Published: 22 January 2020

check for updates

\begin{abstract}
Research on social entrepreneurship (SE) has increased exponentially during the past decade. Even though this social phenomenon has aroused the interest of researchers, many aspects have not yet been fully studied. In this study, the goal is to analyze how the factors that define the behavior of social entrepreneurs are affected by the perception that they have about the development of the social enterprise sector (SES development). We perform an empirical multivariable analysis using 2015 Global Entrepreneurship Monitor (GEM) data related to SE, with an international sample that contains information of 17,778 entrepreneurs, of which 6470 are social entrepreneurs. The empirical analysis is carried out applying binary response models, introducing interaction terms to analyze the moderating effect of SES development. Our results show that the entrepreneurs' perception of the SES development exerts a moderating effect over three different groups of factors: 1) factors related to self-perception about entrepreneurship (including values, perceptions, and entrepreneurial skills); 2) demographic factors (gender, age, and education level), and 3) context and entrepreneurial environment (including factors related to entrepreneurs' perception of societal values, entrepreneurship environment, and economic development). This moderating effect has very important implications, especially for policymakers. Our results show that SES development could amplify some effects, both positively and negatively. Therefore, the design and implementation of policies to support SE must consider the moderating role of this variable on the entrepreneurial behavior, because it could affect the effectiveness of such policies.
\end{abstract}

Keywords: social entrepreneurship; social enterprise sector development; logit analysis; GEM project

\section{Introduction}

Social entrepreneurship (SE) focuses on the use of business management strategies with the aim of generating benefits with a social purpose [1]. The interest in SE by practitioners, policy-makers, and academics has grown exponentially over the past three decades. Its increase on research and its institutionalization in academia reveal that $\mathrm{SE}$ is rapidly gaining maturity [2].

Nonetheless, research on SE still has two main limitations: The lack of a unified definition of SE [3] and the lack of internationally comparable data [4]. Regarding the first limitation, SE is a "simple term with a complex range of meanings" [5], which means that SE is still an unclear and contested concept [6]. Regarding the second limitation, [2] uses a scientometric method to analyze 158 papers and provides an overview of the state of the art on SE research, revealing an important lack of empirical studies (most of them predominately based on qualitative methods) due to the lack of harmonized and comparable international data.

Along this second line of research, it is noticeable that internationally harmonized SE rates do not exist in official statistics [7]. Actually, the scarcity of data on SE activity (SEA) and the 
numerous definitions that exist in literature point to global entrepreneurship monitor (GEM) data as the main source that can help us to get some insights about SE, especially when compared to commercial entrepreneurship.

The environment where the SEA takes place is particularly relevant when we try to explain the differential behavior of social entrepreneurs [8-11]. Mair \& Martí (2006) [12] propose that SE, as occurs in commercial entrepreneurship [13], has to be understood in light of its social and local context, not only taking into consideration purely economic features. Viewing SE as a process that results from ongoing interactions between social entrepreneurs and their context brings together insights from numerous disciplines to enrich our theoretical understanding of this phenomenon. These results show the importance of the environment where the entrepreneurs develop their activity when we study the behavior of the social entrepreneurs, not only for its direct effect on such behavior but also because it may be conditioning how other factors affect social entrepreneurs.

Based on these ideas, the research goal of this study is to analyze the effect of environmental conditions on the characterization of a social entrepreneur's behavior. In particular, we focus our research on the relevance of the perception that social entrepreneurs have about the development of the social enterprise sector (SES development) and its moderating effect on other factors considered in the literature (self-perception about entrepreneurship, demographic factors and context and entrepreneurial environment). For this purpose, it is important to notice that the social enterprise sector (SES) is identified by the existence of businesses focused on the solution of social problems, following the definition proposed in the GEM questionnaire.

In order to achieve this objective, we divide the aim of the paper into two specific objectives. Firstly, we analyze the behavior of the entrepreneurial population, including different variables to study how they influence the probability of being a social entrepreneur. Secondly, we analyze how the entrepreneurs' perception about the SES development could be influencing our first analysis results.

Thus, the main contribution of our research is to provide empirical evidence on the moderating effect that the entrepreneurs' perception of the SES development has on the variables that define the behavior of social entrepreneurs. Based on previous results proposed in the literature, related to the influence of the situation of the sector on businesses, we test the influence of contagion and competition effects on SEA. As far as we know, this is the first attempt to consider the relevance of the SES development for social entrepreneurs. We consider that both the policies to promote SE and their effectiveness could be conditioned by the environment where they are applied. Therefore, exploring such a mediating effect will contribute significant implications to entrepreneurship practitioners.

We perform an empirical multivariable analysis using 2015 GEM harmonized and international data related to SE. The empirical analysis is carried out using multivariate models, introducing interaction terms in the model to analyze the moderating effect of the SES development.

The paper is structured as follows. Firstly, we review the existing literature about the relevance of the environment on SE. Subsequently, the empirical analysis is described, paying attention to the sample used, the estimation strategy, and the results obtained. Finally, we present the main conclusions.

\section{Literature Review}

As professor Dees declared in 1998, SE is a "rare breed" [14]. However, despite the rarity of SE, it presents an evident social importance and scholars have long been interested in better understanding who social entrepreneurs are, what drives them, where they work, and how they interact with others [3].

Even though the definitional debate still persists [6], some characteristics that distinguish social entrepreneurs from commercial entrepreneurs and/or traditional charities have already been identified in previous literature. Among them, the most agreed-upon characteristics are: the predominance of a social mission, the importance of innovation, and the role of earned income [3].

In addition, many papers have studied the determinants and drivers of SE, from a macro level [4,15-17] to a micro level [18-20]. These determinants can be classified according to their 
relationship with (1) the entrepreneur's individual factors or (2) the context and the entrepreneurial environment where social entrepreneurs develop their activities.

\subsection{Entrepreneur's Individual Factors}

First, there are some relevant factors related to self-perception about entrepreneurship, since individuals consider a set of perceptual variables [11] when making decisions about entrepreneurship. These variables include: (a) self-confidence about one's skills and abilities [21-27], (b) knowledge of other entrepreneurs [24-28], (c) alertness to unexploited opportunities [19,24,25,29,30], and (d) likelihood of failure $[20,24-27,30,31]$. All these variables are highly correlated to the decision to start a new business.

Besides, demographic factors such as gender [24-27,32-37], age [24-27,32,33,38], or education $[24-27,32,33,38,39]$ are also important drivers of SE.

\subsection{Context and Entrepreneurial Environment}

In addition to the entrepreneur's individual variables, previous literature has found that context also plays a fundamental role in explaining the behavior of the social entrepreneur [15,40,41]. According to [42], in 2015 the average SEA rate across all 58 GEM economies was 3.2\%. However, SEA rates ranged from $0.3 \%$ (South Korea) to $10.1 \%$ (Peru), showing quite a significant variation among economies.

In relation to the context, one of the main factors considered in previous research has been the level of economic development of countries. In this regard, the most common explanation is that institutional and market failures, which occur in countries with a lower level of economic development, may be behind higher rates of SEA [17]. However, if we consider the impact of cultural values on SE, the relationship between economic development and SE differs $[4,38,43]$. In this sense, post-materialism theories propose a different relationship, arguing that the level of SEA will be higher in more developed economies, since people in these countries could have moral codes more related to post-materialistic values [24,44-46].

Therefore, it might be the case that there are other factors related to context that can be influencing the SEA [15,41,47]. Specifically, [48] highlights the importance of formal and informal institutions, and the fundamental role of the government in supporting the creation of social enterprises. In this regard, governments are adopting numerous measures to create more supportive environments for the development of social enterprises worldwide. Some of these support measures are common to all types of entrepreneurs, such as the administrative considerations of starting a business $[49,50]$, but there are also good practices to enabling environments for social enterprises. Peels et al. (2009) [51] distinguish three classic types of governmental strategies and measures: (1) measures to strengthen a legal framework for social enterprises, (2) mechanisms of direct and indirect government in the market, and (3) instruments to measure the performance and impact.

Next to these actions, governments are also setting up and supporting services to strengthen SE, as those focused on its identification and nurturing. This refers to those policy measures that are taken to support and strengthen education and training in SE, research commissioned on social enterprises and SE, as well as awareness raising activities directed towards the wider public. The aim is to supply information or to raise awareness on $\mathrm{SE}$, where the role of universities can be crucial, fostering regional entrepreneurial ecosystems [52].

Korosec \& Berman (2006) [53] find that public policies can help social entrepreneurs in two ways. First, they increase entrepreneurs' awareness of social problems. Second, they also help them to acquire resources, coordinate themselves with other partners and implement social and/or environmental programs. Their model shows that government support associates with SE positively. Their findings also suggest that perceptions of the municipality as being historically "social minded" also associate with higher levels of perceived SE.

However, the SE promotion policies should go beyond the direct support measures, and should consider the dissemination of information about the activities carried out. In this regard, there is 
a growing interest in the visibility of SE $[42,54]$. Programs such as the European Social Business Initiative [55] also increase awareness of SE in the hope that role model and peer effects will inspire others to get involved in SE. In this way, the existence of a cultural support for entrepreneurship is a relevant factor related with the context where the entrepreneurial activity is carried out.

\subsection{SES Development}

These advances in recent literature highlight the relevance of one key aspect in the study of $\mathrm{SE}$, context, which is addressed in this work. Context plays a crucial role for SE and, therefore, it is specifically interesting to study the influence that the SES development has on the behavior of social entrepreneurs. Along this line, and in order to explore the role of context, we must look at the visibility of SEA, since the influence of the context on social entrepreneurs may be especially conditioned by the entrepreneur's own perception of SES development. In this sense, we must bear in mind that literature has found that the situation of the sector can generate two different effects on companies.

On the one hand, if the sector is not developed or has difficulties, it could reveal negative information about the components of cash flows that are common to all businesses in the sector and, consequently, decrease the market's expectation of the profitability of the sector's businesses [56,57]. This is what is known as the contagion or ripple effect, which assumes that the problems in a sector send a negative signal that affects all the businesses within it. In this context, there would be a disincentive to the entry of new initiatives into this sector. Hunt (2015) finds empirical support to contagion-style market entry for entrepreneurs, who decide to create a new business due to the conditions of the environment [58]. He finds this effect even for unfit businesses that perform poorly and fail quickly.

On the other hand, a sector with businesses in difficulties or with a lower level of development can suppose a positive effect for some of the businesses in this sector, which is known as the competition effect $[59,60]$. This effect could occur because the businesses that are currently operating in the sector are not very efficient, which would generate opportunities for the rest of the competitors and exert a positive effect towards the entry of new initiatives in the sector.

Considering these aspects, the following hypotheses regarding the behavior of the entrepreneurial population are proposed:

Hypothesis 1. the propensity towards social entrepreneurship will be influenced by the perception that entrepreneurs have about the SES development.

Hypothesis 2. the effect of (a) values, perceptions, and entrepreneurial aptitudes, (b) demographic factors, and (c) context and entrepreneurial environment on the propensity towards social entrepreneurship will be moderated by the perception that entrepreneurs have about the SES development.

\section{Empirical Analysis}

\subsection{Sample}

Data was collected from the adult population survey (APS) provided by the global entrepreneurship monitor (GEM). GEM annually collects data from representative samples of at least 2000 randomly selected adults in each of the countries that take part in the project (www.gemconsortium.org). This paper used data from the 2015 survey, when a specific section related to SE was included. In that year, the survey provided specific information about social entrepreneurs in addition to the information about commercial entrepreneurs included every year. The use of this database allows comparing the characteristics that differentiate the social from the commercial entrepreneurs empirically. This contributes to overcoming the lack of empirical studies in SE research, especially studies using quantitative analysis, and using harmonized and comparable international data. According to the extent review of [2], almost $60 \%$ of SE articles address definition, theoretical constructs or frameworks, 
description or understanding of phenomena, typologies, and taxonomies and almost $47 \%$ are purely theoretical or conceptual papers due to the lack of comparable data.

GEM project classifies entrepreneurs using the term "Total early-stage Entrepreneurial Activity (TEA)". To be included in this category, and therefore identified as a commercial entrepreneur using GEM methodology, an individual could be in the phase of "nascent entrepreneurship", when they are actively involved in setting up a business, or in the phase of "new business ownership", when they are owning and managing a business in existence for up to 42 months [42]. In addition, in the 2015 special issue of the GEM report [42], a specific classification for social entrepreneurs is provided, which is defined as "Social Entrepreneurial Activity (SEA)". The GEM methodology considers individuals as social entrepreneurs when they are "starting or currently leading any kind of activity, organization or initiative that has a particularly social, environmental or community objective".

Table 1 shows the sample distribution according to different classification variables used in the GEM project (country, gender, age, and education level). Applying the methodology of the world economic forum (WEF) used in the GEM project, we divided the countries into three different groups: innovation-driven, efficiency-driven, and factor-driven economies. Factor-driven countries are dominated by subsistence agriculture and extraction businesses, with a heavy reliance on (unskilled) labor and natural resources. Efficiency-driven countries are more competitive with more-efficient production processes and increased product quality. Businesses in innovation-driven countries are more knowledge-intensive and these countries strongly rely on the service sector.

Table 1. Sample considering country and classification variables.

\begin{tabular}{|c|c|c|c|c|}
\hline & \multicolumn{2}{|c|}{ Commercial Entrepreneurs } & \multicolumn{2}{|c|}{ Social Entrepreneurs } \\
\hline \multicolumn{5}{|c|}{ Country } \\
\hline Innovation-Driven & 2217 & $19.6 \%$ & 1455 & $22.5 \%$ \\
\hline Efficiency-Driven & 6970 & $61.6 \%$ & 3501 & $54.1 \%$ \\
\hline Factor-Driven & 2121 & $18.8 \%$ & 1514 & $23.4 \%$ \\
\hline Total & 11308 & $100.0 \%$ & 6470 & $100.0 \%$ \\
\hline \multicolumn{5}{|c|}{ Gender } \\
\hline Female & 4951 & $43.8 \%$ & 2817 & $43.5 \%$ \\
\hline Male & 6357 & $56.2 \%$ & 3653 & $56.5 \%$ \\
\hline Total & 11308 & $100.0 \%$ & 6470 & $100.0 \%$ \\
\hline \multicolumn{5}{|c|}{ Age } \\
\hline Under 34 & 5296 & $46.8 \%$ & 2695 & $41.7 \%$ \\
\hline $\begin{array}{l}\text { Between } 34 \text { and } \\
54\end{array}$ & 4989 & $44.1 \%$ & 2700 & $41.7 \%$ \\
\hline Over 54 & 1023 & $9.0 \%$ & 1075 & $16.6 \%$ \\
\hline Total & 11308 & $100.0 \%$ & 6470 & $100.0 \%$ \\
\hline \multicolumn{5}{|c|}{ Education } \\
\hline Primary & 1453 & $12.8 \%$ & 936 & $14.5 \%$ \\
\hline Secondary & 7164 & $63.4 \%$ & 3548 & $54.8 \%$ \\
\hline Higher & 2691 & $23.8 \%$ & 1986 & $30.7 \%$ \\
\hline Total & 11308 & $100.0 \%$ & 6470 & $100.0 \%$ \\
\hline
\end{tabular}

Source: Global Entrepreneurship Monitor (GEM) data (2015).

The sample contained information from 46 different countries, including 17,778 observations (6470 social entrepreneurs and 11,308 commercial entrepreneurs). The GEM survey includes a section in the questionnaire about societal values and entrepreneurship environment that is optional, so not all countries were asked about it. Since the key variable of our study was included in this section, the countries in our sample were only those who answered it. That is, more than one third of the sample was involved in social activities. There were 3672 individuals from 14 countries in innovation-driven 
economies (more than 20 percent of the sample). In the case of efficiency-driven economies, the sample contained 24 countries and 10,471 individuals (almost 60 percent of the sample) and in factor-driven economies, the sample contained eight countries and 3635 individuals (more than 20 percent of the sample). However, the proportion of social entrepreneurs was not homogenous through the sample. Social entrepreneurs had a bigger proportional importance in innovation-driven and in factor-driven economies (Table 1).

If we look at the distribution by gender, the sample shows a higher proportion of men, in the case of both social and commercial entrepreneurs. If we look at the distribution by age, we could observe a greater proportion of individuals over 54 years old in the case of social entrepreneurs. Finally, regarding the level of education, we could observe that the proportion of higher or primary education is greater for social entrepreneurs.

\subsection{Estimation Strategy}

The empirical analysis was carried out applying qualitative response models for discrete endogenous variables. Specifically, we proposed a logit model. In this case, the dependent variable is the probability of being social entrepreneur (ENTREP). The general specification of the model is:

$$
\begin{aligned}
\operatorname{LOG}\left(\frac{\mathrm{P}(\text { ENTREP })}{\mathrm{P}(\text { NO ENTREP })}\right) & \\
& =\beta_{0}+\beta_{1} \text { SUSKILL }_{\mathrm{i}}+\beta_{2} \text { KNOWENT }_{\mathrm{i}}+\beta_{3} \text { OPPORT }_{\mathrm{i}}+\beta_{4} \text { FEARFAIL }_{\mathrm{i}} \\
& +\beta_{5} \text { GENDER }_{\mathrm{i}}+\sum_{\mathrm{k}=1}^{3} \gamma_{\mathrm{k}} \text { AGE }_{\mathrm{i}}+\sum_{\mathrm{z}=1}^{3} \gamma_{\mathrm{z}} \text { EDUCATION }_{\mathrm{i}} \\
& +\beta_{6} \text { CULSUP }_{\mathrm{i}}+\beta_{7} \text { EASYSTART }_{\mathrm{i}}+\beta_{8} \text { NBSOC }_{\mathrm{i}} \\
& +\sum_{\mathrm{y}=1}^{3} \gamma_{\mathrm{y}} \text { COUNTRY }_{\mathrm{i}}+v_{\mathrm{i}} .
\end{aligned}
$$

The dependent variable is a dummy, which identifies those individuals classified as social entrepreneurs (ENTREP). That is, a dummy variable that rates 1 for social entrepreneurs and zero for commercial entrepreneurs. We used the GEM broad definition that identifies a social entrepreneur as "an individual who is starting or currently leading any kind of activity, organization, or initiative that has a particularly social, environmental, or community objective" [42]. Considering this definition, we identified as commercial entrepreneurs the rest of the entrepreneurial population.

As independent variables, we included three groups of variables, following the GEM methodology [61].

The first one includes variables related to self-perception about entrepreneurship, including values, perceptions, and entrepreneurial aptitudes, which are determining factors in making the decision to become an entrepreneur [11]. Specifically, we included four variables, all of them constructed as dummy variables. SUSKILL takes the value 1 for those who think that they have the knowledge, experience, and skills to start a business and zero otherwise. KNOWENT takes the value 1 for those who have had personal contact with someone who has started a business and zero otherwise. OPPORT takes the value 1 for those who perceive opportunities to start a business and zero otherwise. Finally, FEARFAIL takes the value 1 when the possibility of failure discourages the entrepreneur from starting a business and zero otherwise.

The second group includes a set of variables about demographic factors (personal characteristics). A variable related to gender was included in the model (GENDER), as a dummy variable that takes the value 1 in the case of women and zero in the case of men. In order to control for age (AGE), we identified three different groups using dummy variables: those under 34, those between 34 and 54, and those over 54 years old. Finally, to control for education level (EDUCATION), we also identified three groups, depending on whether their level is primary, secondary, or higher education.

The third group included a set of variables related to the context and the entrepreneurship environment, reflecting how people perceive that the environment influences their entrepreneurial behavior and the influence of economic development. In this set, we included different dummy 
variables. CULSUP was calculated according to the cultural support for entrepreneurship index developed by the GEM, taking the value 1 for those who consider that the entrepreneurial culture is high in their country and zero otherwise. EASYSTART takes the value 1 for those who consider that it is easy to open a new business in their country and zero otherwise. NBSOC takes the value 1 for those who consider that it is common to find businesses focused on the solution of social problems in their country and zero otherwise. Finally, three dummy variables were included (COUNTRY), which take the value 1 in the case of innovation-driven, efficiency-driven, and factor-driven economies and zero otherwise.

We focused our interpretation on the odds ratios, which allow a more direct and intuitive interpretation when the independent variables are dichotomous. The odds ratio is obtained by exponentiating the coefficient, so the analyzed effect is on a multiplicative scale-that is, the odds ratios of the dichotomous variables show how much more likely it is to be a social entrepreneur when the independent variable takes the value 1 with respect to when it takes a zero value. When the odds ratio takes values greater than 1 , the influence on the probability is positive; when the values are less than 1 , the influence is negative.

Based on this first model, we analyzed the moderating effect that the entrepreneurs' perception of the SES development in their countries (NBSOC) had on the effect of the three groups of variables that characterize the social entrepreneur. In order to test this moderating effect, we introduced interaction terms in the general model, which allowed us to analyze the influence of each of the variables differentiating the effects for those entrepreneurs who perceive a greater SES development in their countries and for those who do not. The model takes the following form:

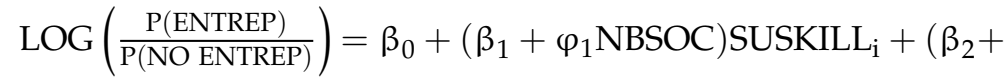

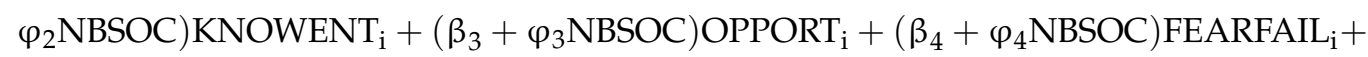

$$
\begin{aligned}
& \left(\beta_{5}+\varphi_{5} \text {NBSOC} \text { GENDER }_{\mathrm{i}}+\sum_{\mathrm{k}=1}^{3}\left(\gamma_{\mathrm{k}}+\varphi_{\mathrm{k}} \mathrm{NBSOC} \mathrm{AGE}_{\mathrm{i}}+\sum_{\mathrm{z}=1}^{3}\left(\gamma_{\mathrm{z}}+\right.\right.\right.
\end{aligned}
$$

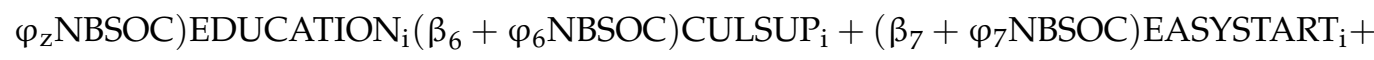

$$
\begin{aligned}
& \sum_{\mathrm{y}=1}^{3}\left(\gamma_{\mathrm{y}}+\varphi_{\mathrm{y}} \text { NBSOC}\right) \text { COUNTRY }_{\mathrm{i}}+v_{\mathrm{i}}
\end{aligned}
$$

The interpretation of the interaction terms in non-linear models cannot be performed directly with the estimated coefficients, which adds complexity to the empirical analysis [62]. In the case of estimates based on odds ratios, the coefficient associated with the interaction variable is a ratio of the two odds ratios associated with the variables that are interacting, which does not allow us to interpret the effect using that coefficient directly. The interpretation must be calculated separately from a combination of the main effects and the interaction coefficients [63]. However, the inclusion of interactions allows obtaining results that are more precise when we need to identify the different influence between two groups of individuals. In our case, the interaction terms improve the capacity of the model to characterize social entrepreneurs according to the entrepreneurs' perception of the SES development in their countries. Following [63,64], we calculated the marginal effect in terms of odds ratios, applying the following procedure: firstly, for each group of individuals defined in the interaction variable (NBSOC), we computed the effect on the probability of being a social entrepreneur when NBSOC takes the values one and zero. Subsequently, we computed the odds ratios as the ratios between these two individual effects, which allowed us to analyze the influence of each variable, differentiating its effect for each group of individuals.

\section{Results}

The results obtained from the estimation of model (1) are presented in Table 2. Model (1) studies the different behavior of social and commercial entrepreneurs based on the independent variables considered in this study. 
Table 2. Results of model (1).

\begin{tabular}{|c|c|c|c|c|c|}
\hline & & \multicolumn{3}{|c|}{ Model (1) } & \multirow[b]{2}{*}{ Sig } \\
\hline & & Odds Ratio & $\mathbf{Z}$ & $p$ Value & \\
\hline \multirow{13}{*}{ Individual factors } & SUSKILL & 0.477 & -18.42 & 0.000 & $* * *$ \\
\hline & KNOWENT & 0.974 & -0.79 & 0.431 & \\
\hline & OPPORT & 0.988 & -0.35 & 0.730 & \\
\hline & FEARFAIL & 1.062 & 1.72 & 0.085 & $*$ \\
\hline & GENDER & 0.948 & -1.65 & 0.098 & * \\
\hline & AGE & & & & \\
\hline & Under 34 & Base & & & \\
\hline & Between 34 and 54 & 1.090 & 2.49 & 0.013 & $* *$ \\
\hline & Over 54 & 2.131 & 14.71 & 0.000 & $* * *$ \\
\hline & EDUCATION & & & & \\
\hline & Primary & Base & & & \\
\hline & Secondary & 0.864 & -2.98 & 0.003 & $* * *$ \\
\hline & Higher & 1.302 & 4.85 & 0.000 & $* * *$ \\
\hline \multirow{8}{*}{$\begin{array}{l}\text { Context and } \\
\text { entrepreneurial } \\
\text { environment }\end{array}$} & CULSUP & 0.996 & -0.12 & 0.902 & \\
\hline & EASYSTART & 0.878 & -3.89 & 0.000 & $* * *$ \\
\hline & NBSOC & 1.047 & 1.34 & 0.180 & \\
\hline & COUNTRY & & & & \\
\hline & Factor-Driven & Base & & & \\
\hline & Efficiency-Driven & 0.622 & -11.45 & 0.000 & $* * *$ \\
\hline & Innovation-Driven & 0.776 & -4.96 & 0.000 & $* * *$ \\
\hline & CONSTANT & 1.358 & 4.03 & 0.000 & $* * *$ \\
\hline
\end{tabular}

Significance level: ${ }^{* * *} 0.01 ;{ }^{* *} 0.05 ;{ }^{*} 0.1$. Source: empirical analyse by the authors.

To confirm that multicollinearity did not actually bias our results, we calculated the variance inflation factors (VIF) for the independent variables included in the model. The value of the VIF indicators should be less than 10, since a value of 1 is a characteristic of an orthogonal system and a value of less than 10 would indicate a non-collinear or stable system [65]. The VIF indicators were smaller than 10 (none of our results show a VIF value greater than 2.33), being the mean VIF 1.35. These results confirmed that our findings were robust to multicollinearity problems.

In the first model, we observed that the perception of SES development in each country (NBSOC) did show no significant influence on the propensity towards SE. Therefore, the hypothesis H1 was not supported by our findings. Nevertheless, this lack of significance might be hiding the two opposing effects that the SES development had on the propensity to start new initiatives (ripple and competition effects).

Therefore, we needed to test $\mathrm{H} 2$ by analyzing the results of model (2). To deepen our knowledge on the influence of the visibility of the SES development on SE, we considered in this model the moderating effect of SES development over the other independent factors. The results of model (2) are presented in Table 3, where we included the variable that considers the entrepreneurs' perception of the SES development (NBSOC) interacted with the other independent variables. The results of model (2) show the odds ratio of each variable for each value of NBSOC (0 or 1), and a statistical test to corroborate if the odds ratios present significant differences between the two groups of individuals.

To analyze the results obtained we would follow this scheme. For each independent variable, we first analyzed its direct effect on the probability that an entrepreneur focuses on social enterprises (Model1, Table 2). Afterwards, we explored the effect of each variable as moderated by the entrepreneurs' perception of the SES development (NBSOC; Model 2, Table 3). 
Table 3. Results of model (2).

\begin{tabular}{|c|c|c|c|c|c|c|}
\hline & & \multicolumn{4}{|c|}{ Model (2) } & \multirow[b]{2}{*}{ Sig. } \\
\hline & & $\mathrm{NBSOC}=0$ & NBSOC $=1$ & $\mathbf{Z}$ & $p$ Value & \\
\hline \multirow{13}{*}{$\begin{array}{l}\text { Individual } \\
\text { factors }\end{array}$} & SUSKILL & 0.491 & 0.463 & -0.73 & 0.463 & \\
\hline & KNOWENT & 0.862 & 0.859 & -0.06 & 0.955 & \\
\hline & OPPORT & 0.915 & 0.809 & -1.81 & 0.071 & * \\
\hline & FEARFAIL & 1.149 & 1.312 & 1.84 & 0.066 & $*$ \\
\hline & GENDER & 1.072 & 0.889 & -2.86 & 0.004 & $* * *$ \\
\hline & AGE & & & & & \\
\hline & Under 34 & & & & & \\
\hline & Between 34 and 54 & 1.043 & 1.167 & 1.55 & 0.121 & \\
\hline & Over 54 & 2.309 & 1.916 & -1.79 & 0.073 & * \\
\hline & EDUCATION & & & & & \\
\hline & Primary & Base & & & & \\
\hline & Secondary & 0.710 & 1.133 & 4.37 & 0.000 & $* * *$ \\
\hline & Higher & 1.118 & 1.598 & 14.06 & 0.000 & $* * *$ \\
\hline \multirow{7}{*}{$\begin{array}{l}\text { Context and } \\
\text { entrepreneurial } \\
\text { environment }\end{array}$} & CULSUP & 0.970 & 0.856 & -1.63 & 0.102 & \\
\hline & EASYSTART & 0.793 & 0.939 & 2.45 & 0.014 & $* *$ \\
\hline & NBSOC & \multicolumn{5}{|c|}{ Moderating variable } \\
\hline & COUNTRY & & & & & \\
\hline & Factor-Driven & Base & & & & \\
\hline & Efficiency-Driven & 0.615 & 0.640 & 0.47 & 0.642 & \\
\hline & Innovation-Driven & 0.745 & 0.891 & 1.61 & 0.108 & \\
\hline
\end{tabular}

Significance level: ${ }^{* * *} 0.01 ;{ }^{* *} 0.05 ;{ }^{*} 0.1$. Source: empirical analyses by the authors.

\subsection{Individual Factors: Values, Perceptions, and Entrepreneurial Aptitudes}

We could observe that perceiving oneself as having the knowledge, experience, and skills to start a business (SUSKILL) reduced the probability that the entrepreneur activity was social (Table 2), since the odds of being a social entrepreneur was less than half comparing to commercial entrepreneurs (0.477). When considering the moderating effect of the entrepreneurs' perception of the SES development, we did not observe statistically significant differences between both groups of entrepreneurs (Table 3).

The second variable, having an entrepreneurial social network (KNOWENT), did not show a significant effect (Table 2), and the moderating effect did not show a difference between the two groups either (Table 3).

In the case of those who perceive opportunities to start a new business (OPPORT), we did not find a differential effect in terms of social versus commercial entrepreneurs, as observed in model (1), where the odd ratio was not statistically significant (Table 2). In this case, the moderating effect was very relevant since the absence of significant influence observed in model (1) was hiding an asymmetric effect that occurred when we considered the entrepreneurs' perception of the SES development (Table 3). On the one hand, in the case of the entrepreneurs with high NBSOC (NBSOC =1), those who perceive opportunities to start a new business (OPPORT) had almost 20 percent less propensity of being social entrepreneurs (odds ratio of 0.809). On the other hand, in the case of the entrepreneurs with low NBSOC $($ NBSOC $=0)$ the influence of the perception of opportunities was only less than 9 percent (odds ratio of 0.915 ).

Finally, the perception of the fear of failure as a disincentive to start a business (FEARFAIL) made the probability of being a social entrepreneur higher (6.2\%, with an odds ratio of 1.062 ; Table 2$)$. When we considered the moderating effect of the entrepreneurs' perception of the SES development, the effect shows different behavior (Table 3). Thus, for entrepreneurs with high NBSOC, there was around 30 percent more probability of being social when they are afraid of failure, so they are less concerned about the lack of success when they consider starting new projects. However, for entrepreneurs with 
low NBSOC, this effect has a smaller magnitude (under 15 percent), although it remains favorable for SE.

Our findings therefore support hypothesis $\mathrm{H} 2 \mathrm{a}$, but only partially because we only find a moderating effect in two of the four factors considered (OPPORT and FEARFAIL).

\subsection{Individual Factors: Demographic Factors}

Regarding GENDER, we observed that women were around 5 percent less likely to be social entrepreneurs (Table 2). However, we observed again a particularly relevant influence of the moderating effect, since the small difference between social and commercial entrepreneurs observed in model (1) again obscured the differential effect that takes place when we consider the entrepreneurs' perception of the SES development (Table 3). Thus, for those entrepreneurs with low NBSOC women show more than 7 percent greater propensity towards SE, while for those with high NBSOC the effect was the opposite, and the propensity of women was lower (more than 11 percent less).

In the case of AGE, we observed that the probability of an entrepreneur being focused on social enterprises was around two times higher for those over 54 years old (Table 2). This difference was reduced for those between 34 and 54 (with a difference around 9 percent). In both cases, the reference group was those entrepreneurs under 34 . In the case of the group of people more focused on SE, those above 54 years old, we could observe that the differences were greater for those entrepreneurs with low NBSOC, that is, these people show a greater propensity to start a social enterprise when they perceive that there is not enough development of this sector in their countries (Table 3).

Finally, for the level of education (EDUCATION), we took those individuals with primary school education as the reference group for analysis, and again the results show a non-linear relationship. In this case, those with a secondary education level were more than 13 percent less likely to be social entrepreneurs (odds ratio of 0.864 ), but this relationship was the opposite in the case of higher education, which exerted a positive influence around 30 percent higher (odds ratio of 1.302; Table 2). In the case of the level of education, the moderating effect was particularly relevant (Table 3 ). The entrepreneurs with a secondary education level and low NBSOC show 29 percent less propensity towards SE, while those with high NBSOC presented the opposite effect, and the propensity was higher (more than 13 percent higher). In the case of entrepreneurs with a higher education level, their perception of the SES development amplified the effect. The propensity towards social activities was almost 60 percent higher for those with high NBSOC (odds ratio of 1.598), while this positive effect was under 12 percent for those with low NBSOC (odds ratio of 1.118).

Our findings therefore supported hypothesis $\mathrm{H} 2 \mathrm{~b}$, since we found a moderating effect for all the demographic factors (GENDER, AGE, and EDUCATION).

\subsection{Context and Entrepreneurial Environment}

First, we observed that the cultural support for entrepreneurship index (CULSUP) had no significant influence in the estimated model (Table 2), and the moderating effect did not show differences (Table 3).

In the case of the perception of the ease of starting a new business (EASYSTART), we found some differences. Firstly, the probability of being a social entrepreneur was lower when they perceive that it is easy to start a new business in their country (odds ratio of 0.878 ; Table 2), because this could be a stronger incentive to be more focused on commercial activities. In this case, the moderating effect was again relevant (Table 3), since the negative significant influence observed in model (1) appeared only for those entrepreneurs with low NBSOC, being that the influence was even greater (odds ratio 0.793). However, in the case of entrepreneurs with high NBSOC the influence was much less relevant (odds ratio of 0.939 ).

The degree of development of the country (COUNTRY) exerted a significant influence on the probability that an entrepreneur focuses on social enterprises (Table 2). As we had three different groups of countries, we analyzed them taking as reference the factor-driven economies. The results show 
a non-linear relationship. In efficiency-driven economies there is almost 38 percent less probability of being a social entrepreneur (odds ratio of 0.622), but this difference was reduced in the case of innovation-driven economies to less than 23 percent (odds ratio of 0.776 ). For this factor, the moderating effect did not show significant differences (Table 3).

Our findings therefore support hypothesis $\mathrm{H} 2 \mathrm{c}$, but only partially because we only found a moderating effect on the variable that exerted a significant influence over the propensity towards SE (EASYSTART), but not for the economic development (COUNTRY).

\section{Discussion}

The research on opportunities identification between social and commercial entrepreneurship is still quite blurred [30]. As previous studies suggest, we found that self-perception of opportunities affected the likelihood to be an entrepreneur [24] but, however, we did not find a differential effect in terms of social versus commercial entrepreneurs [25]. Nevertheless, this could be explained because the competition effect predominated in this case, since the propensity towards SE was lower when the SES was more developed. When entrepreneurs detect business opportunities but at the same time perceive a greater development of social enterprises, they are more focused on commercial activities, probably because the greater competition makes it more difficult to find a market niche in the SES.

As compared to commercial entrepreneurs, social entrepreneurs face a higher risk of failure [66] but, due to their personal motivations, greater fear of failure leads entrepreneurs to enter SE more easily [27]. Our results were consistent with the literature: risk perception reduced the probability to undertake a business [11] but the probability of being a social entrepreneur was higher [25]. Besides, the ripple effect seemed to predominate in this case, since the propensity towards SE was lower when the SES was less developed. Although social entrepreneurs were less affected by fear of failure, this difference was considerably reduced if they perceive less SES development.

Literature indicates that women are more social oriented than men, so the SEA should be greater among them [27,35]. Even though men still prevail [33], the gap in gender in SE is smaller compared to commercial entrepreneurship [36], that is, female entrepreneurs are more equally represented in SE [67]. Besides, following our results, women are more affected by the competition effect, since the propensity towards SE for them is negative when the social enterprise sector is more developed, but positive if they perceive an underdeveloped sector.

Studies have shown different results in relation to the age of the entrepreneur [26,27]. For instance, [32,38] prove that young people create social enterprises to a greater extent. However, [24] does not find significant relationship differences when they compare social and commercial entrepreneurs. Therefore, we found that older entrepreneurs were affected by the competition effect too, since the propensity towards SE for them was smaller when the social enterprise sector was more developed.

As previous literature suggests, our findings also demonstrated that SE increased when the entrepreneurs had higher levels of education $[25,33,38]$. Besides, our results show evidence that as entrepreneurs have higher levels of education, they are more affected by the ripple effect, since the propensity towards SE for them was greater when the social enterprise sector was more developed.

As far as we know, there are not works that analyze the effect of the perception of ease of doing business in the field of SE. In the case of commercial entrepreneurs, [50] found that there is no relation between administrative considerations and the number of entrepreneurs in a country. However, we did find differences on social vs. commercial entrepreneurship, because the probability of being social was lower when individuals perceive that it is easy to start a new business. Moreover, the ripple effect predominated in this case, since the propensity towards SE was lower when the SES was less developed, so the entrepreneurs took advantage of the facilities to open a business and tended to do so in commercial entrepreneurship.

Therefore, to summarize the findings related to the perception of SES development, we found that, on the one hand, there was a competition effect, that is, a lower propensity towards SE when 
the SES was more developed, for those entrepreneurs who detect greater opportunities, for women and for those who are older. That is, when the SES is more developed, entrepreneurs who perceive opportunities in the market are more oriented towards commercial entrepreneurship, seeking to take advantage of those opportunities without facing the barriers that the competition of the SES entails. Similarly, both women and older entrepreneurs perceive that they are less likely to success starting a new social enterprise in a more developed SES.

On the other hand, there is a ripple effect too, that is, a greater propensity towards $\mathrm{SE}$ when the SES is more developed, in entrepreneurs who are more afraid of failure, those who detect facilities to start a new business or those who have a higher level of education. In this case, however, when the SES is more developed, entrepreneurs more afraid about the fear of failure are more oriented towards $\mathrm{SE}$, trying to take advantage of synergies that may exist in that situation. The same effect appears with the facilities to open a new business, which can compensate to a certain extent the higher level of competition in the SES. Finally, entrepreneurs with a higher level of education perceive that this can be an advantage to take advantage of the learning effect offered by a more developed SES.

\section{Conclusions}

When we want to understand the behavior of social entrepreneurs, it is necessary to consider the perception that they have about the development of businesses focused on the solution of social problems in their contexts, because it may condition the relevance that other factors have for this behavior.

The most relevant findings of this paper show the existence of a moderating effect for the entrepreneurs' perception of the SES development. If this influence is not controlled, the results can present relevant biases that can lead to inaccurate conclusions. Our results show that when we controlled for this moderating effect, we could find different relevant effects. Firstly, we found that the magnitude of the relationships changes (FEARFAIL, EASYSTART, AGE, and HIGHER EDUCATION). Secondly, relationships that seemed not to be significant appeared (OPPORT). Finally, in some cases, we found that even the sign of the relationship changed (GENDER and SECONDARY EDUCATION). Therefore, our results show that the ripple and the competition effects appeared when considering the SES development, depending on the factors considered.

This moderating effect has very important implications, especially for policymakers. Our results show that the effects appeared to be amplified, both positively and negatively, for variables of the three groups considered (factors related to self-perception about entrepreneurship, demographic factors and context and entrepreneurial environment). This means that the design and implementation of policies to support SE must consider the differential effect depending on the development of businesses focused on the solution of social problems in the country where they are applied. For example, in the case of lower SES development, policies of awareness and promotion of social entrepreneurship could be more effective when they are focused on women and elder people. However, in the case of higher SES development, the effectiveness of these policies could be improved if they are focused on people with at least a secondary educational level. Our proposal shows that the success of these policies could be due not only to their effectiveness, because the social enterprise environment also plays a fundamental role.

Finally, this study was subject to certain limitations. In this regard, the use of GEM data has many advantages, but also presents some limitations. The GEM includes personal perceptions on the issues analyzed, since it is based on surveys. As we pointed out in our paper, there is no consensus about what is understood by social entrepreneurship, so the perception in each country may be different. In addition, the section in the questionnaire about societal values and the entrepreneurship environment was optional, and not all countries were asked about it. In this section was where the question about SES development was included, so we could not include all the countries of the GEM report in our analysis. However, our sample included a great variety of countries with different level of SES development, allowing us to obtain robust results. 
Our results allowed us to propose future lines of research, in order to deepen the conclusions obtained. Specifically, since there are different types of social entrepreneurs, with greater or lower market orientation and the achievement of social objectives, it would be interesting to analyze the effect that the SES development has based on the type of social entrepreneur affected. Besides, since the results by [68] evidence that half of the variation in entrepreneurship is due to trust matters, it would be interesting to see if the effect of this variable is the same in SE.

Author Contributions: Conceptualization, A.F.-L., C.L.-G. and A.P.; methodology, A.F.-L., C.L.-G. and A.P.; validation, A.F.-L., C.L.-G. and A.P.; formal analysis, A.F.-L., C.L.-G. and A.P.; investigation, A.F.-L., C.L.-G. and A.P.; data curation, A.F.-L., C.L.-G. and A.P.; writing-original draft preparation, A.F.-L., C.L.-G. and A.P.; writing-review and editing, A.F.-L., C.L.-G. and A.P.; visualization, A.F.-L., C.L.-G. and A.P. All authors have read and agreed to the published version of the manuscript.

Funding: This research received no external funding.

Conflicts of Interest: The authors declare no conflict of interest.

\section{References}

1. Kickul, J.; Lyons, T.S. Understanding Social Entrepreneurship: The Relentless Pursuit of Mission in an Ever Changing World; Routledge: New York, NY, USA, 2012.

2. Sassmannshausen, S.P.; Volkmann, C. The scientometrics of social entrepreneurship and its establishment as an academic field. J. Small Bus. Manag. 2018, 56, 251-273. [CrossRef]

3. Lepoutre, J.; Justo, R.; Terjesen, S.; Bosma, N. Designing a global standardized methodology for measuring social entrepreneurship activity: The Global Entrepreneurship Monitor social entrepreneurship study. Small Bus. Econ. 2013, 40, 693-714. [CrossRef]

4. Hoogendoorn, B. The prevalence and determinants of social entrepreneurship at the macro level. J. Small Bus. Manag. 2016, 54, 278-296. [CrossRef]

5. Trexler, J. Social entrepreneurship as an algorithm: Is social enterprise sustainable? Emerg. Complex. Organ. 2008, 10, 65-85.

6. Saebi, T.; Foss, N.J.; Linder, S. Social entrepreneurship research: Past achievements and future promises. J. Manag. 2019, 45, 70-95. [CrossRef]

7. Terjesen, S.; Lepoutre, J.; Justo, R.; Bosma, N. 2009 Report on Social Entrepreneurship; GERA: London, UK, 2012.

8. Omorede, A. Exploration of motivation drivers towards social entrepreneurship. Soc. Enterp. J. 2014, 10, 239-267. [CrossRef]

9. Parker, S.C.; Van Praag, M. Group status and entrepreneurship. J. Econ. Manag. Strateg. 2010, 19, 919-945. [CrossRef]

10. Welter, F. Contextualizing entrepreneurship-Conceptual challenges and ways forward. Entrep. Theory Pract. 2011, 35, 165-184. [CrossRef]

11. Arenius, P.; Minniti, M. Perceptual variables and nascent entrepreneurship. Small Bus. Econ. 2005, 24, 233-247. [CrossRef]

12. Mair, J.; Martí, I. Social entrepreneurship research: A source of explanation, prediction, and delight. J. World Bus. 2006, 41, 36-44. [CrossRef]

13. Ahlstrom, D.; Chang, A.Y.; Cheung, J.S.T. Encouraging entrepreneurship and economic growth. J. Risk Financ. Manag. 2019, 12, 178. [CrossRef]

14. Dees, J.G. Enterprising nonprofits: What do you do when traditional sources of funding fall short? Harv. Bus. Rev. 1998, 76, 54-67. [PubMed]

15. Kerlin, J.A. A comparative analysis of the global emergence of social enterprise. Voluntas 2010, 21, 162-179. [CrossRef]

16. Defourny, J.; Nyssens, M. Conceptions of social enterprise and social entrepreneurship in Europe and the United States: Convergences and divergences. J. Soc. Entrep. 2010, 1, 32-53. [CrossRef]

17. Nissan, E.; Castaño, M.S.; Carrasco, I. Drivers of non-profit activity: A cross-country analysis. Small Bus. Econ. 2012, 38, 303-320. [CrossRef]

18. Short, J.C.; Moss, T.W.; Lumpkin, G.T. Research in social entrepreneurship: Past contributions and future opportunities. Strateg. Entrep. J. 2009, 3, 161-194. [CrossRef] 
19. Bacq, S.; Janssen, F. The multiple faces of social entrepreneurship: A review of definitional issues based on geographical and thematic criteria. Entrep. Reg. Dev. 2011, 23, 373-403. [CrossRef]

20. Ghalwash, S.; Tolba, A.; Ismail, A. What motivates social entrepreneurs to start social ventures? An exploratory study in the context of a developing economy. Soc. Enterp. J. 2017, 13, 268-298. [CrossRef]

21. Hockerts, K. Determinants of social entrepreneurial intentions. Entrep. Theory Pract. 2017, 41, $105-130$. [CrossRef]

22. Bacq, S.; Hartog, C.; Hoogendoorn, B. Beyond the moral portrayal of social entrepreneurs: An empirical approach to who they are and what drives them. J. Bus. Ethics 2016, 133, 703-718. [CrossRef]

23. Clark, K.D.; Newbert, S.L.; Quigley, N.R. The motivational drivers underlying for-profit venture creation: Comparing social and commercial entrepreneurs. Int. Small Bus. J. Res. Entrep. 2018, 36, 220-241. [CrossRef]

24. Nicolás, C.; Rubio, A.; Fernández-Laviada, A. Cognitive determinants of social entrepreneurship: Variations according to the degree of economic development. J. Soc. Entrep. 2018, 9, 154-168. [CrossRef]

25. Nicolás Martínez, C.; Rubio Bañón, A.; Fernández Laviada, A. Social entrepreneur: Same or different from the rest? Voluntas 2019, 30, 443-459. [CrossRef]

26. Estrin, S.; Mickiewicz, T.; Stephan, U. Entrepreneurship, social capital, and institutions: Social and commercial entrepreneurship across nations. Entrep. Theory Pract. Theory Pract. 2013, 37, 479-504. [CrossRef]

27. Estrin, S.; Mickiewicz, T.; Stephan, U. Human capital in social and commercial entrepreneurship. J. Bus. Ventur. 2016, 31, 449-467. [CrossRef]

28. Harding, R. Understanding social entrepreneurship. Ind. High. Educ. 2007, 21, 73-84. [CrossRef]

29. Corner, P.D.; Ho, M. How opportunities develop in social entrepreneurship. Entrep. Theory Pract. 2010, 34 , 635-659. [CrossRef]

30. Lumpkin, G.T.; Moss, T.W.; Gras, D.M.; Kato, S.; Amezcua, A.S. Entrepreneurial processes in social contexts: How are they different, if at all? Small Bus. Econ. 2013, 40, 761-783. [CrossRef]

31. Zahra, S.A.; Gedajlovic, E.; Neubaum, D.O.; Shulman, J.M. A typology of social entrepreneurs: Motives, search processes and ethical challenges. J. Bus. Ventur. 2009, 24, 519-532. [CrossRef]

32. van Ryzin, G.G.; Grossman, S.; DiPadova-Stocks, L.; Bergrud, E. Portrait of the social entrepreneur: Statistical evidence from a US panel. Voluntas 2009, 20, 129-140. [CrossRef]

33. Levie, J.; Hart, M. Business and social entrepreneurs in the UK: Gender, context and commitment. Int. J. Gend. Entrep. 2011, 3, 200-217. [CrossRef]

34. Themudo, N.S. Gender and the nonprofit sector. Nonprofit Volunt. Sect. Q. 2009, 38, 663-683. [CrossRef]

35. Hechavarría, D.M.; Terjesen, S.A.; Ingram, A.E.; Renko, M.; Justo, R.; Elam, A. Taking care of business: The impact of culture and gender on entrepreneurs' blended value creation goals. Small Bus. Econ. 2017, 48, 225-257. [CrossRef]

36. Nicolás, C.; Rubio, A. Social enterprise: Gender gap and economic development. Eur. J. Manag. Bus. Econ. 2016, 25, 56-62. [CrossRef]

37. Dimitriadis, S.; Lee, M.; Ramarajan, L.; Battilana, J. Blurring the boundaries: The interplay of gender and local communities in the commercialization of social ventures. Organ. Sci. 2017, 28, 819-839. [CrossRef]

38. Vuorio, A. Young adults and sustainable enterpreneurship: The role of culture and demographic factors. J. Int. Bus. Entrep. Dev. 2017, 10, 209-230. [CrossRef]

39. Bravo, C. Identifying Cross-Country Key Drivers of Social Entrepreneurial Activity. Ph.D. Thesis, University of San Diego, San Diego, CA, USA, 2017.

40. Austin, J.; Stevenson, H.; Wei-Skillern, J. Social and commercial entrepreneurship: Same, different, or both? Entrep. Theory Pract. 2006, 30, 1-22. [CrossRef]

41. Mair, J. Social entrepreneurship: Taking stock and looking ahead. In Handbook of Research in Social Enterpreneurship; Edward Elgar: Cheltenham, UK, 2010; pp. 20-32.

42. Bosma, N.; Schøtt, T.; Terjesen, S.; Kew, P. Social Entrepreneurship; GERA: London, UK, 2015.

43. Witte, C.T. Cultural Determinants of Social Entrepreneurship. Master's Thesis, Erasmus University Rotterdam, Rotterdam, The Netherlands, 2013.

44. Inglehart, R. Globalization and postmodern values. Wash. Q. 2000, 23, 215-228. [CrossRef]

45. Inglehart, R.; Welzel, C. Modernization, Cultural Change, and Democracy. The Human Development Sequence; Cambridge: Cambridge, MA, USA, 2005.

46. Schofer, E.; Fourcade-Gourinchas, M. The structural contexts of civic engagement: Voluntary association membership in comparative perspective. Am. Sociol. Rev. 2001, 66, 806-828. [CrossRef] 
47. Anheier, H.K. Nonprofit Organizations: Theory, Management, Policy; Routledge: New York, NY, USA, 2005.

48. Stephan, U.; Uhlaner, L.M.; Stride, C. Institutions and social entrepreneurship: The role of institutional voids, institutional support, and institutional configurations. J. Int. Bus. Stud. 2015, 46, 308-331. [CrossRef]

49. Djankov, S.; La Porta, R.; Lopez-de-Silanes, F.; Shleifer, A. The regulation of entry. Q. J. Econ. 2002, CXVII, 437-452. [CrossRef]

50. Van Stel, A.; Storey, D.J.; Thurik, A.R. The effect of business regulations on nascent and young business entrepreneurship. Small Bus. Econ. 2007, 28, 171-186. [CrossRef]

51. Peels, R.; Gijselinckx, C.; Van Opstal, W.; Zhao, L. Enabling Environments for Social Enterprise Development. Analytical Framework and International Exploratory Study of Good Practices; Katholieke Universiteit Leuven: Leuven, Belgium, 2009.

52. Ierapetritis, D.G. Discussing the role of universities in fostering regional entrepreneurial ecosystems. Economies 2019, 7, 119. [CrossRef]

53. Korosec, R.L.; Berman, E.M. Municipal support for social entrepreneurship. Public Adm. Rev. 2006, 66, 448-462. [CrossRef]

54. Teasdale, S.; Lyon, F.; Baldock, R. Playing with numbers: A methodological critique of the social enterprise growth myth. J. Soc. Entrep. 2013, 4, 113-131. [CrossRef]

55. European Commission. The Social Business Initiative of the European Commission. Internal Market and Services; European Commission: Brussels, Belgium, 2011.

56. Lang, L.H.P.; Stulz, R.M. Contagion and competitive intra-industry effects of bankruptcy announcements. An empirical analysis. J. Financ. Econ. 1992, 32, 45-60. [CrossRef]

57. Kennedy, R.E. The effect of bankruptcy filings on rivals' operating performance: Evidence from 51 large bankruptcies. Int. J. Econ. Bus. 2000, 7, 5-25. [CrossRef]

58. Hunt, R.A. Contagion entrepreneurship: Institutional support, strategic incoherence, and the social costs of over-entry. J. Small Bus. Manag. 2015, 53, 5-29. [CrossRef]

59. Iqbal, Z. The effects of bankruptcy filings on the competitors' earnings. Int. Rev. Econ. Financ. 2002, 11, 85-99. [CrossRef]

60. Zhang, G. Emerging from chapter 11 bankruptcy: Is it good news or bad news for industry competitors? Financ. Manag. 2010, 39, 1719-1742. [CrossRef]

61. Reynolds, P.; Bosma, N.; Autio, E.; Hunt, S.; De Bono, N.; Servais, I.; Lopez-Garcia, P.; Chin, N. Global Entrepreneurship Monitor: Data collection design and implementation 1998-2003. Small Bus. Econ. 2005, 24, 205-231. [CrossRef]

62. Norton, E.C.; Wang, H.; Ai, C. Computing interaction effects and standard errors in logit and probit models. Stata J. 2004, 4, 154-167. [CrossRef]

63. Buis, M.L. Stata tip 87: Interpretation of interactions in nonlinear models. Stata J. 2010, 10, 305-308. [CrossRef]

64. Hilbe, J.M. Logistic Regression Models; Chapman \& Hall/CRC: New York, NY, USA, 2009.

65. Chatterjee, S.; Haidi, A.S. Regression Analysis by Example; John Wiley \& Sons: Hoboken, NJ, USA, 2012.

66. Renko, M. Early challenges of nascent social entrepreneurs. Entrep. Theory Pract. 2013, 37, $1045-1069$. [CrossRef]

67. Teasdale, S.; McKay, S.; Phillimore, J.; Teasdale, N. Exploring gender and social entrepreneurship: Women's leadership, employment and participation in the third sector and social enterprises. Volunt. Sect. Rev. 2011, 2, 57-76. [CrossRef]

68. Kodila-Tedika, O.; Agbor, J. Does trust matter for entrepreneurship: Evidence from a cross-section of countries. Economies 2016, 4, 4. [CrossRef]

(C) 2020 by the authors. Licensee MDPI, Basel, Switzerland. This article is an open access article distributed under the terms and conditions of the Creative Commons Attribution (CC BY) license (http://creativecommons.org/licenses/by/4.0/). 